\title{
Soil fauna changes across Atlantic Forest succession
}

\author{
Claudia Reis Ferreira' Maria Elizabeth Fernandes Correia'², Rodrigo Camara', \\ Alexander Silva Resende², Lúcia Helena Cunha dos Anjos', Marcos Gervasio Pereira'*
}

\footnotetext{
'Federal Rural University of Rio de Janeiro, Brazil

${ }^{2}$ Brazilian Agricultural Research Corporation, Brazi

*Corresponding author, e-mail: gervasio@ufrrj.br
}

\begin{abstract}
The soil fauna can be used as a bioindicator of soil quality and ecosystem functioning. The present study aimed to assess the effect of the Atlantic Forest secondary succession on the structure and composition of the soil fauna community in Itaboraí, Rio de Janeiro. We selected five areas along a gradient of forest succession: pasture (PA) and four forest fragments (FF1, FF2, FF3, FF4), which are in a toposequence. Thus, we divided the areas in upper, middle and lower thirds and delimitated a transect $(20 \mathrm{~m})$ in each third. In the dry season 2010 , a metalic square $(0.25 \mathrm{~m} \times 0.25 \mathrm{~m})$ was released in five points spaced $5 \mathrm{~m}$ apart, in each transect. The soil fauna was manually captured on samples of the litter standing stock and blocks of the topsoil $(0.00-$ $0.10 \mathrm{~m}$ ), circumscribed to the square, in the forest fragments. In PA, we colected only the topsoil blocks. The complexity of the structure and composition of the soil fauna community increased in the topsoil and litter standing stock, along the successional gradient. However, the similarity among the areas was much greater in the litter standing stock, in comparison to the topsoil.
\end{abstract}

Keywords: forest succession, pasture area, soil biota

\section{Introduction}

The Atlantic Forest is known internationally because of its high levels of richness and endemism of plant species (Murray-Smith et al., 2009). However, currently, there are only a few small and isolated forest fragments of this biome, which are in different stages of secondary succession (Ribeiro et al., 2009). Thus, several species have become endangered due to the loss and fragmentation of habitat (Biodiversitas, 2016), and studies focused on ecosystem functioning, structure, and composition of animal and plant communities may contribute to the recovery and preservation of the forest remnants.

The structure and species composition of the plant communities change along the forest succession (Marín-Spiotta et al., 2007; Menezes et al., 2009), as the microclimate conditions change (Negrete-Yankelevich et al., 2007). As a result, ecosystem functioning so as litterfall, litter standing stock and decomposition also change, during the forest development (Ostertag et al., 2008; Pinto et al., 2008; Mateus et al., 2013). In terms of litter decomposition, the role of the soil fauna is prominent (Mayer, 2008).

The soil fauna community responds to variations within the forest succession (Younger et al., 2005; Negrete-Yankelevich et al., 2007; Menezes et al. 2009; Camara et al., 2012; Rousseau et al., 2014; Machado et al., 
2015). Therefore, the soil fauna may function as a bioindicator of soil quality and ecosystem functioning along this process. If negative impact is observed in the community of such organisms, the human intervention is needed to facilitate the forest succession. However, it is necessary to conduct more studies with this approach, to identify consistent patterns of the response of the soil organisms to different stages of the forest succession (Sylvain \& Wall, 2011).

The present study aimed to assess the effect of the Atlantic Forest secondary succession on the structure and composition of the soil fauna community in Itaboraí, Rio de Janeiro.

\section{Material e methods}

The study area is located between latitudes $22^{\circ} 40^{\prime} 30$ "S and $22^{\circ} 38$ '42" S, and longitudes 4248 '.54 "W and 42 47' 42" $\mathrm{W}$, in the municipality of Itaboraí, state of Rio de Janeiro. The area is at an altitude of $27 \mathrm{~m}$ (Gonçalves,
2014). According Köppen (1948), the climate is tropical Aw, that is, with rainy summers and dry winters. The annual average temperature is 21.4 ${ }^{\circ} \mathrm{C}$ and higher values occur from January to March, while the smaller from June to August, according to Gonçalves (2014) (Figura 1). This author also pointed that the total annual rainfall is $1,461 \mathrm{~mm}$, the rainiest months are December and January, while June and July are the months with less precipitation. The predominant soil type in the region is Oxisoil (Gomes et al., 2014).

Most of the original vegetation of the region, which is Dense Ombrophilous Forest of lowland and lower montane (Veloso et al., 1991), was eliminated primarily for installation of pastures and crops, as well as logging and extraction of sand and clay. Thus, the matrix area corresponds to abandoned pastures, among which are observed some small fragments of secondary forest ( $<5$ ha) on the top of the slopes.

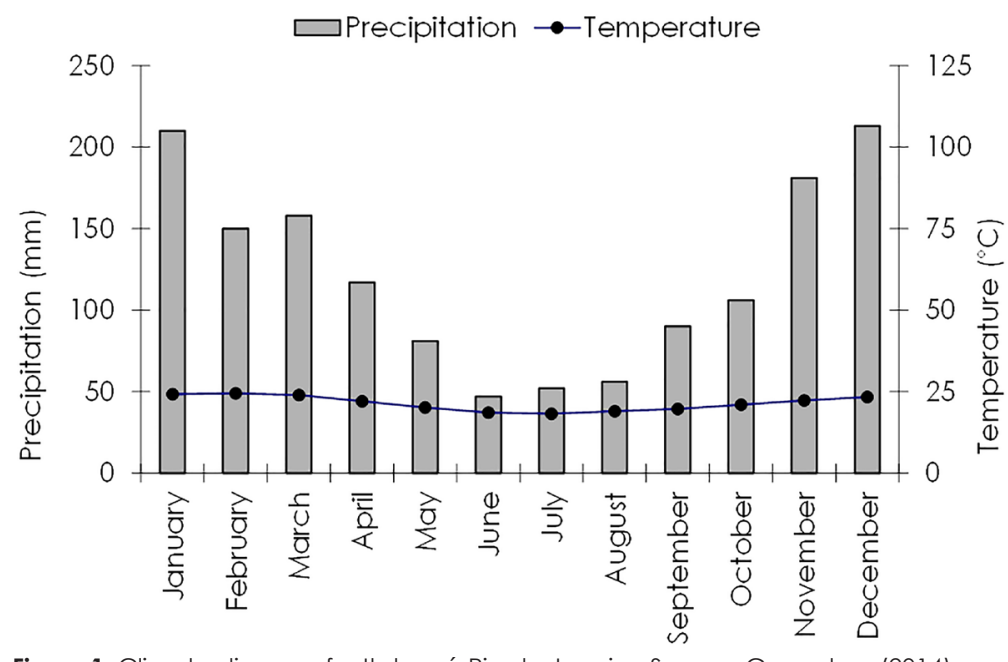

Figure 1. Climate diagram for Itaboraí, Rio de Janeiro. Source: Gonçalves (2014).

For the present study, we selected an abandoned pasture area (PA) and four forest fragments, which are in an increasing gradient of natural regeneration: FF1, FF2, FF3 and FF4 (Uhlmann et al., 2014). The forest fragments vary in size: FF3 presents the higher area (21 ha), followed by FF1 (10 ha), FF2 (7,5 ha), and FF4 (3 ha) (Scoriza, 2012). According to Uhlmann et al. (2014), the tree community in FFl has the lowest values of richness (15 tree species) and diversity (1.11), which both of them gradually increase in FF2 (16 and 1.63, respectively) through FF3 (28; 2.39), and reach the highest values in FF4 $(37 ; 3.17)$. In PA, predominates Brachiaria decumbens Stapf., which did not occurre in the forest fragments.

The areas of study occur in a toposequence and, therefore, they were subdivided into three sections: upper, middle and lower thirds. In May 2010 (dry season), we delimitated a transect (20 $\mathrm{m}$ length) in each third and released a metalic square $(0.25 \mathrm{~m} \times 0.25 \mathrm{~m})$ in five points at least $5 \mathrm{~m}$ apart from each other, in each transect (Pasqualin et al., 2012). The soil fauna was manually captured on samples of the litter standing stock and blocks of the topsoil (0.00$0.10 \mathrm{~m}$ ), circumscribed to the square, according to the method proposed by the Tropical Soil 
Biological and Fertility program (TSBF), described by Anderson and Ingram (1993). In PA, only the topsoil blocks were collected. Thus, we obtained a total of 15 samples of the litter standing stock and blocks of the topsoil in each forest fragment, and 15 samples of the topsoil in PA. Each sample was considered an experimental unit.

The samples were individually packed in plastic bags previously identified. In the field, these materials were transferred into a tray where the organisms were manually extracted, with the aid of tweezers. The organisms were individually stored in vials with $70 \%$ alcohol. Subsequently, in the laboratory, the organisms were identified by naked or under binocular magnifying lens, if necessary, and quantified in large taxonomic groups (order, class, family). Formicidae and Enchytraeidae were both considered a taxon apart of Hymenoptera and Oligochaeta, respectively. The adults were separated from juvenile forms (pupa) and larval forms even when they belonged to the same taxonomic group, due to the differences between these vital stages in terms of their ecological role in the soil environment (Odum, 1988). Taxonomic groups were further categorized according to their trophic guilds (Menezes et al., 2009; Camara et al., 2012; Silva et al., 2013; Rousseau et al., 2014). Thus, some of them were categorized in: predators, saprophagous, and herbivorous (Table 2). In contrast, some taxonomic groups included edaphic organisms with belonged to more than one trophic guild. In these cases, they were categorized as: predators/saprophagous, saprophagous/herbivorous, or saprophagous/ microphagous.

We estimated the values of the structural attributes of the soil community: total density (D) and density of the taxonomic groups $\left(\mathrm{m}^{-2}\right.$ individuals), total richness or number of the taxonomic groups (S), equability (U, Pielou index) and diversity (H', Shannon index) (Odum, 1988). The community composition was evaluated according to the following criteria: absence/ presence of the taxonomic groups; relative contribution (\%) of the taxonomic groups; density of the taxonomic groups; density of the trophic guilds. The relative contribution was calculated as the ratio between the density of each group and the density of the community. The taxonomic groups with a low relative contribution (< 1\%) in both litter standing stock and topsoil, were reunited as the group "Other".

The mean values of abundance (community and taxonomic groups) were compared by the nonparametric Kruskal-Wallis test ( $p<0.05$ ), with BioEstat software version 5.3 (Mamirauá Institute, Belém). We obtained a hierarchical dendrogram clustering by single linkage, based on Euclidean distance, with the aim of discriminating the areas. For this purpose, we considered the mean abundance of the taxonomic groups, individually in each compartment (litter standing stock/topsoil) and each section of the slope (upper, middle and lower third). We also performed a principal component analysis (PCA) with the aim of obtain the correlation among the structural attributes of the edaphic fauna within the topsoil and litter standing stock, and the dry mass of the litter standing stock and the chemical attributes of the leaf litter lying on the soil surface (Scoriza, 2012). According to this author, leaves predominated in the litter standing stock (47,5\% of the total) at the forest fragments. Both of these multivariate analyses were performed by PAST software, version 2.17c (Hammer et al., 2001).

\section{Results and Discussion}

The effect of the Atlantic Forest succession on the structure of the soil fauna community

We extracted a total of 8,173 organisms which were distributed in 34 taxonomic groups. All of these groups occurred in at least one of the forest fragments. In the topsoil, the number of organisms obtained was 1.065 (approximately $13.0 \%$ of the total), 666 (8.1\%), 861 (10.5\%) and 3.421 (41 9\%) in FF1, FF2, FF3 and FF4, respectively. On the other hand, in the PA (topsoil) we extracted 1,149 individuals (approximately $14.1 \%$ of the total), distributed in 12 taxonomic groups. The higher number of individuals caught in FF4 was due to the high relative contribution of Formicidae and Isoptera in the upper third, which represented $60 \%$ and $35 \%$ of the whole community on this site, respectively. In the litter standing stock of the forest fragments were captured 305 (3.7\%), 256 (3.1\%), 308 (3.8\%) and 
$142(1.7 \%)$ individuals in FF1, FF2, FF3 and FF4, respectively.

The total amount of the captured organisms in the forest fragments was at least 2.5 times greater in the topsoil, when compared to the litter standing stock. This pattern was also observed in areas of Montane Tropical Rainforest in Mexico with different ages (15, 45, 75 and 100 years) (Negrete-Yankelevich et al., 2007), and fragments of Atlantic Forest at different stages of natural regeneration (early, medium and advanced stages) in Pinheiral, RJ (Menezes et al., 2009).

The lowest values of richness were found in FF2-UT (litter standing stock) and FF2-MT (topsoil), while higher values occurred in FF4-UT (litter standing stock), FF4-LT (topsoil) and FF1-MT (litter standing stock) (Table 1). The equability was lower in FFI-UT (litter standing stock) and FFI-LT (topsoil), while the highest values were verified in FF4-MT (both litter standing stock and topsoil) and FF4-LT (litter standing stock). In terms of diversity, the lowest values were observed in FF1-UT (litter standing stock) and FFI-LT (topsoil); in contrast, the highest values of this variable occurred in FF4LT (litter standing stock), FF4-MT (topsoil) and FF1MT (topsoil).

Table 1. Structural attributes of the soil fauna community structure within litter standing stock and topsoil in the upper, middle and lower thirds (UT, MT and LT, respectively) at a pasture area (PA) and four forest fragments in an increasing gradient of natural regeneration (FF1, FF2, FF3, and FF4), Itaboraí, RJ*.

\begin{tabular}{|c|c|c|c|c|c|c|c|c|}
\hline \multirow[t]{2}{*}{ Area } & \multicolumn{4}{|c|}{ Litter standing stock } & \multicolumn{4}{|c|}{ Topsoil $(0,00-0,10 \mathrm{~cm})$} \\
\hline & $\mathrm{D}$ & $S$ & $U$ & $\mathrm{H}^{\prime}$ & $\mathrm{D}$ & $S$ & $U$ & $\mathrm{H}$ \\
\hline PA-UT & - & - & - & - & 666 (163) & 14 & 0.69 & 2.63 \\
\hline PA-MT & - & - & - & - & $899(486)$ & 11 & 0.48 & 1.65 \\
\hline PA-LT & - & - & - & - & $2,112(1,176)$ & 11 & 0.49 & 1.68 \\
\hline Average PA & - & - & - & - & $1,226(431)$ & 16 & 0.55 & 2.18 \\
\hline FFl-UT & 307 (116) & 9 & 0.48 & 1.52 & $621(270)$ & 15 & 0.64 & 2.48 \\
\hline FFl-MT & 554 (192) & 14 & 0.62 & 2.36 & $310(76)$ & 11 & 0.86 & 2.98 \\
\hline FFl-LT & $115(29)$ & 12 & 0.80 & 2.88 & $2,477(2,269)$ & 11 & 0.19 & 0.66 \\
\hline Average FFl & 325 (42) & 18 & 0.56 & 2.34 & $1,136(375)$ & 17 & 0.41 & 1.68 \\
\hline FF2-UT & 74 B (36) & 5 & 0.74 & 1.71 & 803 (474) & 10 & 0.49 & 1.62 \\
\hline FF2-MT & 624 (293) & 8 & 0.56 & 1.68 & $576(276)$ & 9 & 0.58 & 1.84 \\
\hline FF2-LT & $122(45)$ & 8 & 0.65 & 1.95 & $752(166)$ & 15 & 0.68 & 2.66 \\
\hline Average FF2 & $273(57)$ & 11 & 0.57 & 1.98 & 710 (92) & 17 & 0.54 & 2.21 \\
\hline FF3-UT & 525 A (114) & 10 & 0.49 & 1.63 & $1,533(1,073)$ & 14 & 0.24 & 0.90 \\
\hline FF3-MT & $237(56)$ & 12 & 0.81 & 2.89 & $358(85)$ & 11 & 0.73 & 2.54 \\
\hline FF3-LT & $224(80)$ & 13 & 0.78 & 2.90 & 864 (701) & 11 & 0.35 & 1.20 \\
\hline Average FF3 & $329(30)$ & 20 & 0.61 & 2.65 & $918(208)$ & 20 & 0.47 & 2.02 \\
\hline FF4-UT & $192(65)$ & 14 & 0.70 & 2.67 & $9,542(9,203)$ & 13 & 0.34 & 1.25 \\
\hline FF4-MT & $93(23)$ & 9 & 0.83 & 2.62 & $298(86)$ & 11 & 0.86 & 2.98 \\
\hline FF4-LT & 170 (49) & 13 & 0.83 & 3.06 & 1,107 (452 & 17 & 0.53 & 2.18 \\
\hline Average FF4 & $151(14)$ & 20 & 0.71 & 3.08 & $3,649(1,528)$ & 22 & 0.36 & 1.61 \\
\hline
\end{tabular}

The mean values of the structural attributes calculated among the upper, middle and lower third, considering all of the stages of succession (PA, FF1, FF2, FF3 and FF4), indicated that richness increased in both ecosystem compartiments (litter standing stock and topsoil), with the advance of the forest regeneration (Table 1). On the other hand, while the values of equability and diversity tended to decrease in topsoil, both of them tended to increase in the litter standing stock, along the forest regeneration gradient (from FF1 to FF4, through FF2 and FF3).
Considering the results in Table 1, we observed that the complexity of the structure of the soil fauna community increased (increasing values of richness, equability, and diversity) as the process of forest regeneration advanced. This pattern was also observed by others authors, which pointed that it occurred by two factors: both abiotic and food resource conditions are more favorable to the soil fauna in more advanced stages of forest tropical succession (Negrete-Yankelevich et al., 2007; Menezes et al., 2009; Szinwelski et al., 2012; Rousseau et al., 2014; 
Machado et al., 2015).

As the successional gradient progresses, the plant community undergoes an increasing in its structure (Marín-Spiotta et al., 2007), which is reflected in an increased litterfall (Pinto et al., 2008) and, consequently, in largest litter standing stock (Mateus et al., 2013). Such conditions, combined with a more closed canopy in forests with more advanced sucessional stage (Menezes et al., 2009) contribute to lower temperatures and higher water content in the soil, compared to the young forests (Negrete-Yankelevich et al., 2007; Szinwelski et al., 2012).

In addition, the forest fragments in more advanced stages of succession becomes more rich and diverse in tree species (Marin-Spiotta et al., 2007; Menezes et al., 2009). In more diverse forest ecosystems, there is a complementarity between the tree species, which present different uptake rates of nutrients from the soil (Gama-Rodrigues et al., 2007). Thus, in such cases the litterfall is more heterogeneous (Correia \& Andrade, 2008) and there is a greater variety of niches that allows a soil fauna community with higher richness (Coimbra et al., 2007), compared with those in the less advanced stages of succession (Maharning et al., 2009).

However, although the same pattern of the present study has occurred in terms of richness, Camara et al. (2012) verified that both of the values of equability and diversity were lower in advanced successional stages. According to these authors, it occurred due to a few taxonomic groups that were favored in the advanced successional stages compared with those at less advanced stages.

In general, there was no significant difference among the areas (PA, FF1, FF2, FF3 and FF4) in the case of the density within both the topsoil $(p=0.1364)$ and litter standing stock $(p=0.0518)$. This was due to the non-random behavior and aggregation of the soil organisms, which influenced the high values of the standard error (Table 1). The only one exception was the significantly higher density in FF3-UT when compared to FF2-UT.

The absence of differences between pasture areas and/or Atlantic Forest fragments in different stages of natural regeneration with respect to density or abundance of the soil fauna community also occurred in Pinheiral, RJ (Menezes et al., 2009) and Curitiba, PR (Schmidt et al., 2008), as in areas of the Brazilian Forest Amazon (Rousseau et al., 2014). However, Negrete-Yankelevich et al. (2007), Cunha \& Orlando (2011), Camara et al. (2012), Szinwelski et al. (2012), and Machado et al. (2015) observed higher density or abundance values in the advanced stages of tropical forest succession.

The effect of the Atlantic Forest succession on the composition of the soil fauna community

Based on presence/absence, 14 taxonomic groups (41\% of the total richness) occurred in all sampled ecosystem (the five areas) at least in one of the compartments analyzed (topsoil/litter standing stock) (Table 2). This was the case of Araneae, Blattodea, Chilopoda, Coleoptera (larvae, pupae, and adults), Diplopoda, Formicidae (larvae and adults), Isoptera, Isopoda, Oligochaeta (cocoons and adults) and Orthoptera. All of these groups were also observed in different successional stages in the Eastern Brazilian Amazon (Rousseau et al., 2014).

Among these taxonomic groups, only Chilopoda, Isoptera, and Blattodea were not considered as generalists by Machado et al. (2015), while Oligochaeta was not found by these authors in areas with three different successional stages of the Atlantic Forest. Araneae, Blattodea, Coleoptera (larvae and adults), Formicidae (adults), Isoptera, Isopoda, and Orthoptera also occurred in a native preserved forest and two abandoned eucalyptus plantations in different stages of Atlantic Forest regeneration, while Chilopoda and Oligochaeta were not sampled in these three areas by Camara et al. (2012), in the state of Rio de Janeiro.

Acari, Auchenorrhyncha, Heteroptera, and Opilionida (12\% of the total richness) presented a no defined pattern of occurrence, considering the increasing gradient of the forest regeneration (Table 2). No group was restricted to the PA (Table 2).

In contrast, 16 taxonomic groups $(47$ $\%$ of the total richness) presented a pattern in its occurrence along the forest regeneration 
Table 2. Occurrence (presence/absence) of the soil fauna taxonomic groups within the topsoil (TPS) and litter standing stock (LSS) at a pasture area (PA) and four forest fragments in an increasing gradient of natural regeneration (FF1, FF2, FF3, and FF4), Itaboraí, RJ*.

\begin{tabular}{|c|c|c|c|c|c|c|c|c|c|}
\hline \multirow[t]{2}{*}{ Group } & \multirow{2}{*}{$\begin{array}{l}\text { PA* } \\
\text { TPS }\end{array}$} & \multicolumn{2}{|c|}{ FFl } & \multicolumn{2}{|c|}{ FF2 } & \multicolumn{2}{|c|}{ FF3 } & \multicolumn{2}{|c|}{ FF4 } \\
\hline & & LSS & TPS & LSS & TPS & LSS & TPS & LSS & TPS \\
\hline \multicolumn{10}{|l|}{ Predators } \\
\hline Araneae & $x$ & $x$ & $x$ & $x$ & $x$ & $x$ & $x$ & $x$ & $x$ \\
\hline Chilopoda & $x$ & $x$ & $x$ & $x$ & $x$ & $x$ & $x$ & $x$ & $x$ \\
\hline Hymenoptera & - & $x$ & - & - & - & - & - & - & - \\
\hline Neuroptera & - & - & - & - & - & - & - & $x$ & - \\
\hline Opilionida & - & $x$ & - & - & - & - & $x$ & $x$ & - \\
\hline Pseudoscorpionida & - & $x$ & - & $x$ & - & $x$ & - & $x$ & $x$ \\
\hline Scorpionida & - & - & - & - & - & $x$ & - & - & - \\
\hline \multicolumn{10}{|l|}{ Predators/saprophagous } \\
\hline Acari & - & $x$ & - & - & - & $x$ & $x$ & $x$ & $x$ \\
\hline Coleoptera & $x$ & $x$ & $x$ & $x$ & $x$ & $x$ & $x$ & $x$ & $x$ \\
\hline Formicidae & $x$ & $x$ & $x$ & $x$ & $x$ & $x$ & $x$ & $x$ & $x$ \\
\hline Isoptera & $x$ & $x$ & $x$ & $x$ & $x$ & $x$ & $x$ & $x$ & $x$ \\
\hline Coleoptera's larvae & $x$ & $x$ & $x$ & - & $x$ & $x$ & $x$ & - & $x$ \\
\hline Diptera's larvae & - & - & - & - & $x$ & $x$ & $x$ & $x$ & $x$ \\
\hline Lepidoptera's larvae & - & $x$ & - & - & $x$ & $x$ & - & - & - \\
\hline Trichoptera's larvae & - & $x$ & - & $x$ & - & $x$ & - & $x$ & $x$ \\
\hline Coleoptera's juvenile & $x$ & $x$ & - & $x$ & - & $x$ & $x$ & $x$ & - \\
\hline Thysanoptera & - & - & - & - & - & $x$ & - & - & - \\
\hline \multicolumn{10}{|l|}{ Saprophagous } \\
\hline Archaeognatha & - & - & - & - & - & $x$ & $x$ & - & $x$ \\
\hline Blattodea & $x$ & $x$ & $x$ & $x$ & $x$ & - & $x$ & $x$ & $x$ \\
\hline Diplopoda & $x$ & $x$ & $x$ & $x$ & $x$ & $x$ & $x$ & $x$ & $x$ \\
\hline Diplura & - & - & $x$ & - & $x$ & $x$ & $x$ & - & $x$ \\
\hline Enchytraeidae & - & - & - & - & - & - & - & - & $x$ \\
\hline Isopoda & $x$ & $x$ & $x$ & $x$ & $x$ & $x$ & $x$ & $x$ & $x$ \\
\hline Oligochaeta & $x$ & $x$ & $x$ & $x$ & $x$ & $x$ & $x$ & $x$ & $x$ \\
\hline Symphyla & - & - & $x$ & - & $x$ & $x$ & $x$ & - & $x$ \\
\hline Thysanura & - & - & $x$ & $x$ & - & $x$ & $x$ & $x$ & $x$ \\
\hline \multicolumn{10}{|c|}{ Saprophagous/herbivorous } \\
\hline Gastropoda & - & $x$ & $x$ & $x$ & $x$ & - & $x$ & $x$ & $x$ \\
\hline \multicolumn{10}{|c|}{ Saprophagous/microphagous } \\
\hline Entomobryomorpha & - & - & - & - & - & $x$ & - & $x$ & - \\
\hline \multicolumn{10}{|l|}{ Herbivorous } \\
\hline Auchenorryncha & $x$ & - & $x$ & - & - & - & $x$ & $x$ & $x$ \\
\hline Diptera & - & $x$ & - & $x$ & - & $x$ & $x$ & $x$ & - \\
\hline Heteroptera & $x$ & $x$ & - & - & - & $x$ & - & $x$ & $x$ \\
\hline Orthoptera & $x$ & $x$ & - & - & $x$ & - & $x$ & $x$ & - \\
\hline \multicolumn{10}{|l|}{ No defined function } \\
\hline Oligochaeta's cocoon & $x$ & - & $x$ & - & $x$ & - & $x$ & $x$ & $x$ \\
\hline Formicidae's larvae & $x$ & $x$ & $x$ & $x$ & - & $x$ & - & $x$ & $x$ \\
\hline
\end{tabular}

gradient. Thus, these groups were considered indicators of the stages of the ecosystem development. Diptera's larvae (predators/ saprophagous) were not captured only in PA and FF1 (Table 2). Diplura, Symphyla, and Thysanura (all saprophagous), Gastropoda (saprophagous/ herbivorous), Trichoptera (larvae and adults, both of them saprophagous/predators), Pseudoscorpionida (predators), and Diptera (herbivorous) were not found only in PA (Table 2).
Lepidoptera's larvae (predators/saprophagous) also did not occur in PA and FF4, but this taxonomic group was sampled in the other forest fragments (topsoil/litter standing stock).

As a result, both the total richness and the number of the representative taxonomic groups within all trophic guilds were lower in the PA (topsoil), compared to the forest fragments. Thus, the more favorable microclimate conditions and more heterogeneous food resources 
availability (litter) contributed to the increased complexity of the composition of soil fauna community in forest ecosystems compared to PA, regardless of the natural regeneration stage. When there is functional redundancy within the community, that is, when different taxonomic groups coexist within the same trophic guild, the energy redistribution is more balanced along the trophic chains, which show that the ecological functioning of the ecosystem presents higher stability (Menezes et al., 2009).

Hymenoptera (predators) was only observed in FFl (litter standing stock) (Table 2). Archaeognatha and Enchytraeidae (both saprophagous), Neuroptera and Scorpionida (both predators), Entomobryomorpha (saprophagous/microphagous), and Thysanoptera (predators/saprophagous) only occurred in FF3 and/or FF4, at least in one of the compartments (topsoil/litter standing stock). This result highlighted that the number of the taxonomic groups belonging to different trophic guilds, increased as advanced the stage of forest regeneration.

Pseudoscorpionida is considered as an indicator of native forest ecosystems in the good state of preservation (Souza et al., 2008). Pseudoscorpionida and Diplura were both absent in a pasture area, but they occurred in forest fragments in four and three different stages of succession, respectively, in the Brazilian Amazon (Rousseau et al., 2014). Archaeognatha, Diplura, and Thysanura were restricted to a preserved native forest, and they were not found in two abandoned eucalyptus plantations with different stages of natural regeneration of Atlantic Forest (Camara et al., 2012).

According to Camara et al. (2012), the relative contribution of Entomobryomorpha increased from $5 \%$ to $30 \%$ in the dry season and from $8 \%$ to $65 \%$ in the rainy season, over the Atlantic Forest succession process within abandoned eucalyptus plantations. Archaeognatha, Pseudoscorpionida, and Thysanura were sampled only in the intermediate and advanced stage of succession, while Gastropoda only occurred in the later stage, but none of these taxonomic groups were found in the early stage of secondary regeneration of the
Atlantic Forest (Machado et al., 2015).

In terms of the percentage participation of the taxonomic groups, in general, there was a decrease in the relative contribution of Formicidae (predators/saprophagous), both in topsoil and litter standing stock); Oligochaeta adults (saprophagous) and cocoons (no defined function), both in topsoil; and Coleoptera's larvae (predators/saprophagous) in topsoil, as advanced the regeneration of the forest (Figure 2). However, there was an increase in the relative contribution of Araneae (predators), in litter standing stock, over the increasing gradient of forest regeneration. This same result occurred in topsoil, for Isoptera (predators/saprophagous); Isopoda (saprophagous); and, Other, even if this pattern has not occurred gradually, along the increasing gradient of succession. The relative contribution and/or density/abundance of Formicidae were also negatively impacted, as the opposite occurred for Araneae, which was positively impacted, within the succession of the Atlantic Forest (Menezes et al., 2009; Camara et al., 2012).

According to the average of all of the forest fragments, most of the individuals (> 50\%) that belonged to 29 taxonomic groups were extracted from the litter standing stock (Figure 3). This pattern was verified for Pseudoscorpionida and Araneae (predators), Isopoda and Diplopoda (saprophagous), Formicidae (predators/ saprophagous), and "Others". This latter group was represented by individuals distributed in 24 taxonomic groups, which belonged to different trophic guilds. Probably the availability of food resources was higher in the litter standing stock, in comparison to the topsoil, for most captured taxonomic groups.

However, for a smaller amount of taxonomic groups (five), the opposite pattern was observed for the vertical distribution. In the average calculated among the forest fragments, the preference for the topsoil was observed for Chilopoda (predators); Oligochaeta (saprophagous); Isoptera and Coleoptera's larvae (both predators/saprophagous); and Oligochaeta's cocoons (Figure 3). The latter group refers to the egg stage of Oligochaeta, which do not feed, and therefore do not belong 


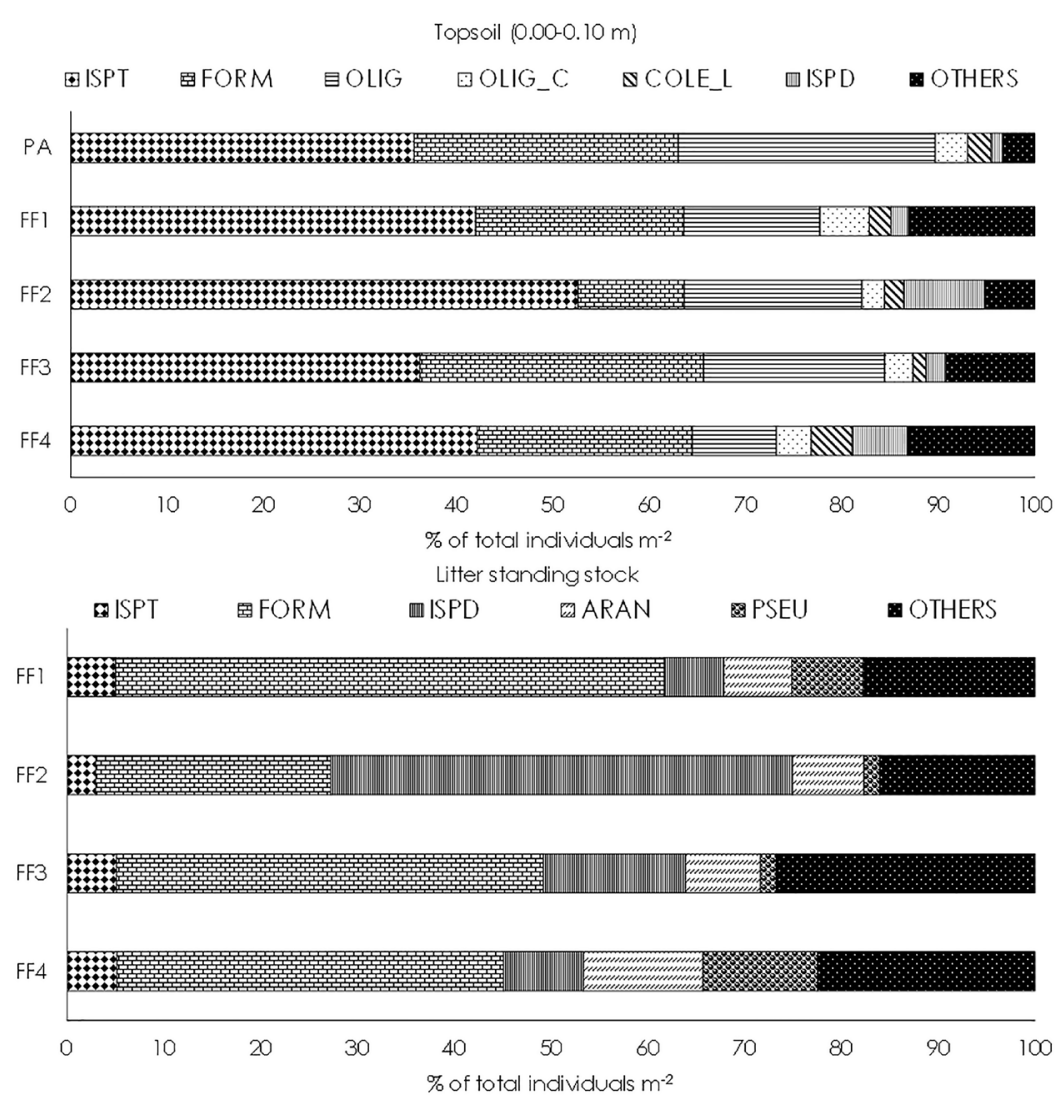

Figure 2. Relative contribution (\%) of the soil fauna taxonomic groups within the topsoil and litter standing stock at a pasture area (PA) and four forest fragments in an increasing gradient of natural regeneration (FF1, FF2, FF3, and FF4), Itaboraí, RJ. ISPT: Isoptera; FORM: Formicidae; OLIG: Oligochaeta; OLIG_C: Oligochaeta's cocoon; COLE_L: Coleoptera's larvae; ISPD: Isopoda; OTHERS; ARAN: Araneae; PSEU: Pseudoscorpionida.

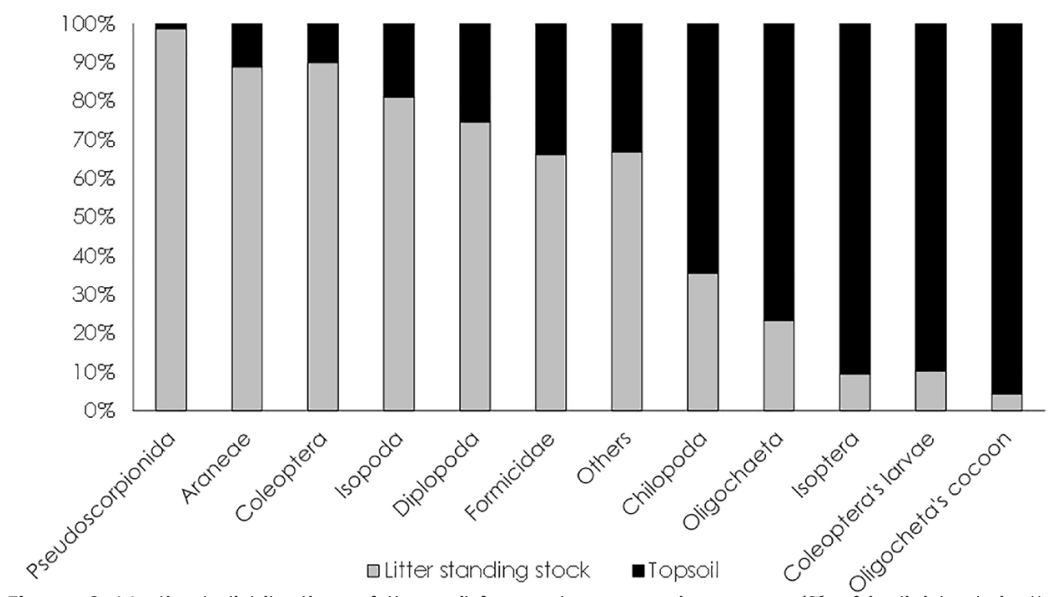

Figure 3. Vertical distribution of the soil fauna taxาonomic groups (\% of individuals in the average for the forest fragments) within the litter standing stock and topsoil, Itaboraí, RJ.

to any trophic guild.

This pattern was expected to Isoptera and Oligochaeta, whose main activity occurred in the topsoil, compared with the litter standing stock in forest fragments in three different stages of Atlantic Forest succession (Menezes et al., 2009). The higher incidence of Chilopoda in the topsoil, in relation to the litter standing stock, also occurred in a preserved forest in Restinga da
Marambaia, RJ, both in the dry and rainy seasons (Silva et al., 2013).

Regarding the density of the trophic guilds, there were no significant differences among the soil fauna community of all of the five areas, in terms of the herbivorous (topsoil: $\mathrm{p}=0.2333$; litter standing stock: $\mathrm{p}=0.1034$ ), saprophagous/herbivorous (topsoil: $p=0.9970$; litter standing stock: $p=0.9935)$, saprophagous / 
microphagous (topsoil: $p=1.0000$; litter standing stock: $p=0.9595)$. This result also occured for predators/saprophagous in the topsoil $(\mathrm{P}=$ 0.3849), whereas the density of this trophic group was significantly higher $(p<0.05)$ in PA compared to FF2, in the litter standing stock.

However, there were significant differences $(p<0.05)$ among the areas in relation to the other trophic guilds. The density of the saprophagous was higher in PA compared to FF1, FF3 and FF4, in the topsoil, and was higher in PA compared to all four forest fragments, in the litter standing stock. On the other hand, the density of the predators was higher in FFl, FF3, and FF4 compared to PA, and higher in FF3 and FF4 compared to FF2, both in the topsoil, and was also higher in FF1, FF3, and FF4 in relation to PA, in the litter standing stock.

In general, the trophic guilds of predators and saprophagous were both favored within the forest ecosystem development. These guilds were negatively affected by the replacement of Atlantic Forest by eucalyptus plantations (Camara et al., 2012), and in areas within less advanced stages of succession, in the Brazilian Amazon (Morais et al., 2010). These guilds are sensitive to human impacts, which can decrease the primary resources for the trophic chains

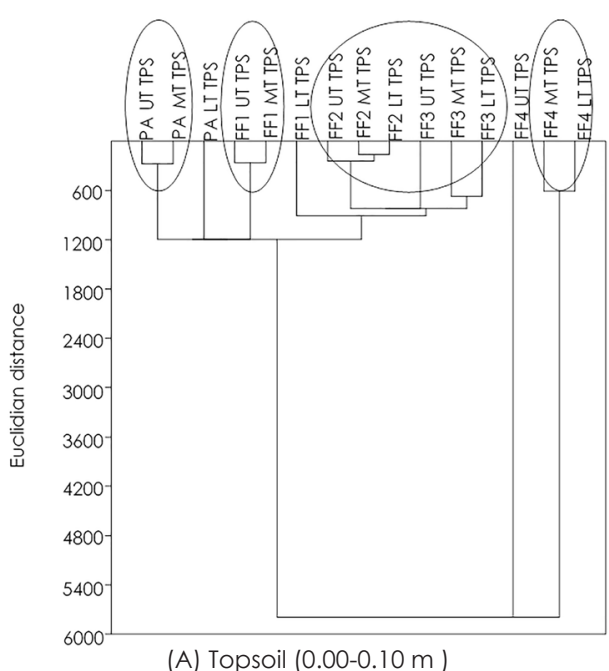

(Negrete-Yankelevich et al., 2007), and are important for the nutrient cycling (Correia \& Andrade, 2008). Thus, taxonomic groups of the soil fauna that belong to the guilds of predators and saprophagous should be considered indicators of soil quality (Menezes et al., 2009).

The cluster analysis based on the average abundance of the soil fauna taxonomic groups within the topsoil showed the low similarity that all areas presented to each other (Figure 4A). When comparing areas of tropical forest in different stages of succession, the similarity among them may be low, even when the values of the soil fauna richness are very close to each other (SCHMIDT \& DIEHL, 2008). According to these authors, this indicates that some groups are restricted to a certain stage of succession, thus the soil fauna composition may be more useful than richness to monitor the community.

However, FF2 and FF3 formed a small group and thus presented higher similarity to each other, in comparison to the other areas (Figura 4A). These two areas also formed a macro group with PA and FFl, which revealed a relative similarity among themselves. In contrast, this macro group presented high dissimilarity with respect to FF4, that was itself isolated from the other areas.

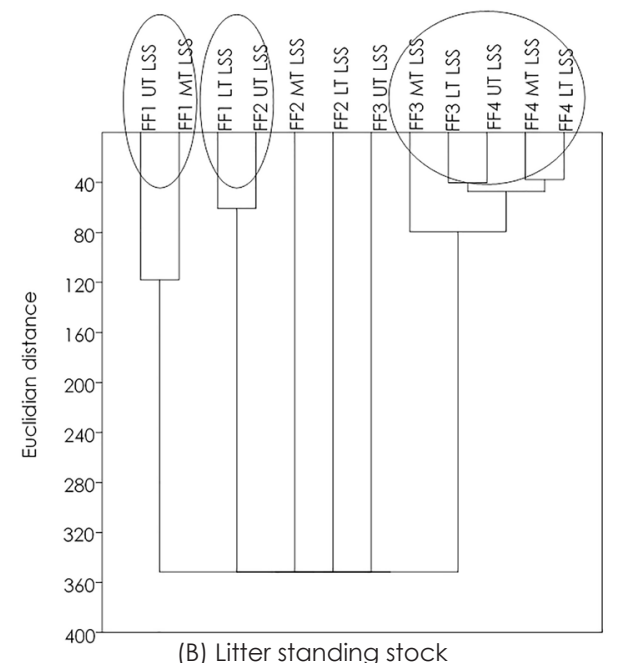

(B) Litter standing stock

Figure 4. Hierarchical clustering obtained by the average density of the taxonomic groups within the topsoil (TPS) (A) and litter standing stock (LSS) (B) in lower, middle, and upper thirds (UT, MT, and LT, respectively) at a pasture area (PA) and four forest fragments in an increasing gradient of natural regeneration (FF1, FF2, FF3, and FF4), Itaboraí, RJ.

With regard to the litter standing stock, while the FFl was still distant from other forest fragments, it expressed similarity to FF2, at least with respect to the upper third (Figure $4 \mathrm{~B}$ ). On the other hand, the soil fauna community in both FF1 and FF2 areas showed low similarity with the community in FF3 and FF4. These two later areas formed a group, which indicated the similarity 
between them.

Thus, the complexity of both the structure and composition of the soil fauna community was lower in PA and FFl, but increased along the successional gradient (Figure 4). In fact, the community in FF3 showed higher similarity to FF4. However, this pattern occurred differently when comparing the topsoil and litter standing stock. This was based on the large difference in the values of the Euclidean distance scale for each one of these compartiment (Figure 4). The scale which compares the areas with each other showed 6.000 as the maximum distance value, in the dendrogram of the topsoil (Figure 4A). This value was 15 times greater than the value of the maximum distance in the dendrogram of the litter standing stock, which about 400 (Figure 4B).

Therefore, the similarity among the areas was higher when considering the litter standing stock, in comparison to the topsoil. In this later compartment, the soil fauna community still had high dissimilarity compared between all areas, and FF4 showed higher distance from the PA, FF1, FF2, and FF3. This demonstrated that the soil fauna community in FF4 can be considered "climax", compared to other areas.

In the principal component analysis
(PCA), the straght-line segments represent the structural attributes of the edaphic fauna or the attributes of the litter standing stock (Scoriza, 2012), and points represent the forest fragments (FF1, FF2, FF3, and FF4). The PCA explained more than $83 \%$ of the data variance. The axis 1 (principal component 1) explained $50 \%$ of data and axis 2 (principal component 2) explained only $33 \%$.

Along the axis 1 (main axis), the Atlantic Forest fragments in less advanced stage of natural regeneration (FF1, FF2, and FF3) were grouped in the left portion, while the forest fragment in more advanced stage of natural regeneration (FF4) remained isolated in the right portion (Figure 5). Besides, this analysis also demonstrated that FF2, FF3, and F4 are in a gradient of natural forest regeneration, according to their positions along the axis 1. In addition, FF2 and FF3, which are in intermediate stages of forest regeneration, were both positioned very close to each other at the left portion of the axis 2, whereas FF4 remained isolated at the right portion of this axis. Thus, the soil fauna community acted as a bioindicator of the stage of natural forest regeneration, in the area of study.

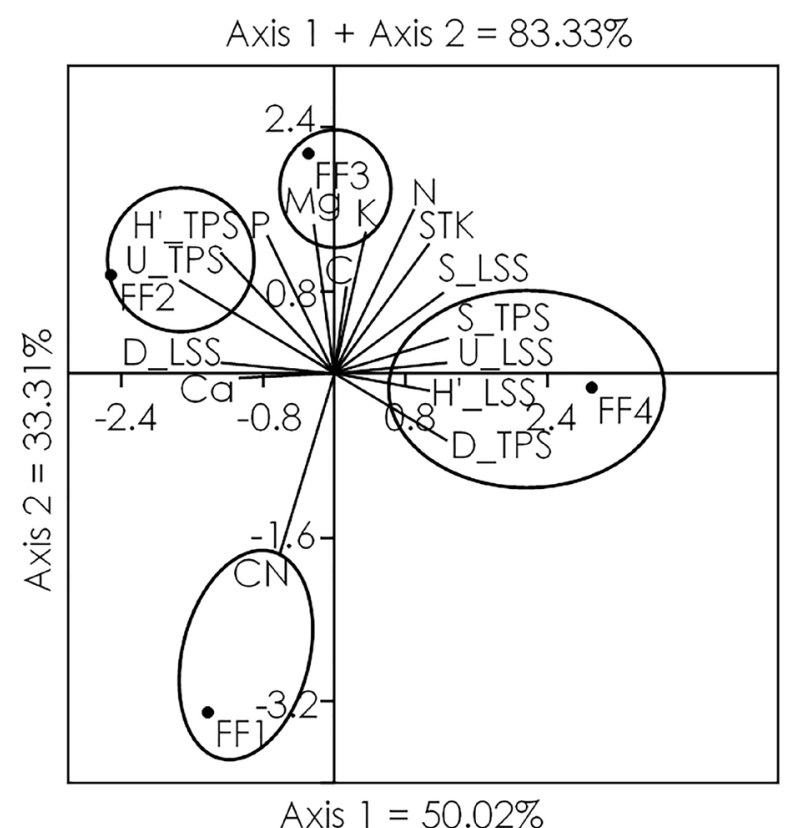

Figure 5. Principal components analysis of the structural attributes of the edaphic fauna community within the topsoil (TPS) and litter standing stock (LSS), and the dry mass of the litter standing stock and the chemical attributes of the leaf litter lying on the soil surface (Scoriza, 2012) in the forest fragments in an increasing gradient of natural regeneration (FF1, FF2, FF3, and FF4), Itaboraí, RJ. D: density, individuals m-2; S: total richness (number) of taxonomic groups; U: equability index; H': diversity index; STK: dry weight of the litter standing stock; C, N, P, K, Ca, Mg, and $\mathrm{C} / \mathrm{N}$ : carbon, nitrogen, phosphorous, potassium, calcium, magnesium concentrations and $\mathrm{C} / \mathrm{N}$ ratio, respectively. 
The Figure 5 indicated that $\mathrm{FFl}$ was more correlated by the $\mathrm{C} / \mathrm{N}$ ratio of the leaf litter lying on the soil surface, which was significantly higher in this area in comparison to FF2, FF3, and FF4 (Scoriza, 2012). On the other hand, the concentrations of $\mathrm{K}$ and $\mathrm{Mg}$ were best correlated to FF3, due to the higher values of both leaf litter chemical attributes (Scoriza, 2012). These results agreed to Boeger et al. (2005), which observed that the concentrations of $\mathrm{N}$ and $\mathrm{K}$ are higher in leaves of tree species that occurs in areas with more advanced stage of Atlantic forest. Thus, the lower concentration of nitrogen, associated with the highest concentration of carbon, would result in the increase of $\mathrm{C} / \mathrm{N}$ ration in leaves of the litter standing stock in $\mathrm{FFl}$.

The increase of $\mathrm{N}$ and $\mathrm{K}$ concentrations in the leaves probable occurred as a consequence of the higher depth of the litter standing stock in advanced stages fo forest natural regeneration (Boeger et al., 2005). This patter was also verified in the areas studied, because the litter standing stock was significantly lower in $\mathrm{FFl}$, in comparison to FF2, FF3, and FF4 (Scoriza, 2012). This is a reflection of the higher litterfall, which increases by the higher tree community structure, in more advanced stages of forest regeneration (Chazdon, 2012).

FF2 presented higher correlations to both equability and diversity in the topsoil, because of the higher values of these attributes, in comparison to the other forest fragments (Table 1). However, most of the structural attributes of the edaphic fauna within the topsoil (density and richness) and the litter standing stock (equability and diversity) presented higher correlation to the FF4. This pattern corroborated the fact that the complexity of the edaphic community increased as the natural regeneration of the Atlantic Forest advanced, in the area of study.

\section{Conclusions}

The complexity of the structure and composition of the edaphic fauna community increased in the topsoil and litter standing stock, along the successional gradient. However, the similarity among the areas was much greater in the litter standing stock, in comparison to the topsoil.

\section{References}

Anderson, J.N., Ingram, J.S.I. 1993. Tropical soil biology and fertility: a handbook of methods. CAB International, Wallingford. $171 \mathrm{p}$.

Biodiversitas. 2016. Lista oficial de espécies ameaçadas de extinção no Brasil. http://www. biodiversitas.org.br/florabr/grupo3fim.asp. <Acesso em 29 Jul. 2016>

Boeger, M.R.T., Wisniewski, C., Reissmann, C.B. 2005. Nutrientes foliares de espécies arbóreas de três estádios sucessionais de floresta ombrófila densa no sul do Brasil. Acta Botanica Brasilica 19: p.167-181

Camara, R., Correia, M.E.F., Villela, D.M. 2012. Effects of eucalyptus plantations on soil arthropod communities in a Brazilian Atlantic Forest conservation. Bioscience Journal 28: 445455.

Chazdon, R. 2012. Regeneração de florestas tropicais. Boletim do Museu Paraense Emílio Goeldi Ciências Naturais 7: 195-218

Coimbra, J.L.M., Santos, J.C.P., Alves, M.V., Barzotto, I. 2007. Técnicas multivariadas aplicadas ao estudo da fauna do solo: contrastes multivariados e análise canônica discriminante. Revista Ceres 54: 270-276.

Correia, M.E.F., Andrade, A.G. 2008. Formação de serapilheira e ciclagem de nutrientes. In: Santos, G.A., Camargo, F.A.O. (ed.) Fundamentos da matéria orgânica do solo: ecossistemas tropicais e subtropicais. Gênesis, Porto Alegre, RS. p. 137170.

Cunha, H.F., Orlando, T.Y.S. 2011. Functional composition of termite species in areas of abandoned pasture and in secondary succession of the Parque Estadual Altamiro de Moura Pacheco, Goiás, Brazil. Bioscience Journal 27: 986-992.

Gama-Rodrigues, A.C., Barros, N.F., Comerford, N.B. 2007. Biomass and nutrient cycling in pure and mixed stands of native tree species in southeastern Bahia, Brazil. Revista Brasileira de Ciência do Solo 31: 287-298.

Gomes, J.B.V., Curcio, G.R., Dedecek, R.A., Ramos, M.R. 2014. Atributos químicos e mineralógicos. In: Prado, R.B., Fidalgo, E.C.C., Bonnet, A. (ed.) Monitoramento da revegetação do COMPERJ: etapa inicial. Embrapa, Brasília, DF. p. 103-118.

Gonçalves, A.O. 2014. Caracterização climática. In: Prado, R.B., Fidalgo, E.C.C., Bonnet, A. (ed.) Monitoramento da revegetação do COMPERJ: etapa inicial. Embrapa, Brasília, DF. p. 65-81. 
Hammer, $\varnothing$., Harper, D.A.T., Ryan, P.D. 2001. PAST: Paleontological statistics software package for education and data analysis. Palaeontologia Electronica 4: 1-9. http://palaeo-electronica. org/2001_1/past/issuel_01.htm. <Access on 14 Apr. 2015>

Köppen, W. 1948. Climatologia: con un estudio de los climas de la Tierra. Fondo de Cultura Economica, Mexico. 478 p.

Machado, D.L., Pereira, M.G., Correia, M.E.F., Diniz, A.R., Menezes, C.E.G. 2015. Fauna edáfica na dinâmica sucessional da Mata Atlântica em floresta estacional semidecidual na bacia do Rio Paraíba do Sul - RJ. Ciência Florestal 25: 91-106.

Maharning, A.R., Mills, A.A.S., Adl, S.M. 2009. Soil community changes during secondary succession to naturalized grasslands. Applied Soil Ecology 41: 137-147.

Marín-Spiotta, E., Ostertag, R., Silver, W.L. 2007. Long-term patterns in tropical reforestation: plant community composition and aboveground biomass accumulation. Ecological Applications 17: 828-839.

Mateus, F.A., Miranda, C.C., Valcarcel, R., Figueiredo, P.H.A. 2013. Estoque e capacidade de retenção hídrica da serrapilheira acumulada na restauração florestal de áreas perturbadas na Mata Atlântica. Floresta e Ambiente 20: 336-343.

Mayer, P.M. 2008. Ecosystem and decomposer effects on litter dynamics along an old field to old-growth forest successional gradient. Acta Oecologica 33: 222-230.

Menezes, C.E.G., Correia, M.E.F., Pereira, M.G., Batista, I., Rodrigues, K.M., Couto, W.H., Anjos, L.H.C., Oliveira, I.P. 2009. Macrofauna edáfica em estádios sucessionais de floresta estacional semidecidual e pastagem mista em Pinheiral (RJ). Revista Brasileira de Ciência do Solo 33: 1647-1656.

Morais, J.W., Oliveira, V.S., Dambros, C.S., TapiaCoral, S.C., Acioli, A.N.S. 2010. Mesofauna do solo em diferentes sistemas de uso da terra no Alto Rio Solimões, AM. Neotropical Entomology 39: 145-152.

Murray-Smith, C., Brummitt, N.A., Oliveira-Filho, A.T., Bachman, S., Moat, J., Lughadha, E.M.N., Lucas, E.J. 2009. Plant diversity hotspots in the Atlantic Coastal Forests of Brazil. Conservation Biology 23: 151-163.

Negrete-Yankelevich, S., Fragoso, C., Newton, A.C., Heal, O.W. 2007. Successional changes in soil, litter and macroinvertebrate parameters following selective logging in a Mexican Cloud Forest. Applied Soil Ecology 35: 340-355.
Odum, E.P. 1988. Ecologia. Editora Guanabara Koogan, Rio de Janeiro, Brasil. 434 p.

Ostertag, R., Marín-Spiotta, E., Silver, W.L., Schulten, J. 2008. Litterfall and decomposition in relation to soil carbon pools along a secondary forest chronosequence in Puerto Rico. Ecosystems 11:330 228.

Pasqualin, L.A., Dionísio, J.A., Zawadneak, M.A.C., Marçal, C.T. 2012. Macrofauna edáfica em lavouras de cana-de-açúcar e mata no noroeste do Paraná - Brasil. Semina: Ciências Agrárias 33: 7-18.

Ribeiro, M.C., Metzger, J.P., Martensen, A.C., Ponzoni, F.J., Hirota, M.M. 2009. The Brazilian Atlantic Forest: How much is left, and how is the remaining forest distributed? Implications for conservation. Biological Conservation 142: 1141 1153.

Pinto, S.I.C., Martins, S.V., Barros, N.F., Dias, H.C.T. 2008. Produção de serapilheira em dois estádios sucessionais de Floresta Estacional Semidecidual na Reserva Mata do Paraíso, em Viçosa, MG. Revista Árvore 32: 545-556.

Rousseau, G.X., Silva, P.R.S., Celentano, D., Carvalho, C.J.R. 2014. Macrofauna do solo em uma cronosequência de capoeiras, florestas e pastos no Centro de Endemismo Belém, Amazônia Oriental. Acta Amazonica 44: 499-512.

Sabu, T.K., Shiju, R.T., Vinod, K.V., Nithya, S. 2011. A comparison of the pitfall trap, Winkler extractor and Berlese funnel for sampling ground-dwelling arthropods in tropical montane cloud forests. Journal of Insect Science 11:1-19.

Schmidt, F.A., Diehl, E. 2008. What is the effect of soil use on ant communities? Neotropical Entomology 37: 381-388.

Schmidt, P., Dickow, K., Rocha, A.A., Marques, R., Schevermann, L., Römbke, J., Förster, B., Höfer, H. 2008. Soil macrofauna and decomposition rates in southern Brazilian Atlantic rainforests. Ecotropica 14: 89-100.

Scoriza, R.N. 2012. Indicadores ambientais na interface solo-serrapilheira e suas Interações em fragmentos de Floresta Atlântica. 63p. (M.Sc. Dissertation) - Federal Rural University of Rio de Janeiro, Seropédica, Brazil.

Silva, C.F., Pereira, G.H.A., Pereira, M.G., Silva, A.N. 2013. Fauna edáfica em área periodicamente inundável na restinga da Marambaia, RJ. Revista Brasileira de Ciência do Solo 37: 587-595.

Sylvain, Z.A., Wall, D.H. 2011 . Linking soil biodiversity and vegetation: implications for a changing planet. American Journal of Botany 98: 517-527. 
Szinwelski, N., Rosa, C.S., Schoereder, J., Mews, C.M., Sperber, C.F. 2012. Effects of forest regeneration on crickets: evaluating environmental drivers in a 300-year chronosequence. International Journal of Zoology 2012: 1-13.

Uhlmann, A., Bonnet, A., Curcio, G.R., Silva, A.P., Gonçalves, F.L.A., Resende, A.S. 2014. A cobertura vegetal das florestas e pastagens. In: Prado, R.B., Fidalgo, E.C.C., Bonnet, A. (ed.) Monitoramento da revegetação do COMPERJ: etapa inicial. Embrapa, Brasília, DF. p. 223-244

Veloso, H.P., Rangel Filho, A.L.R., Lima, J.C.A. 1991. Classificação da vegetação brasileira adaptada a um sistema universal. IBGE, Rio de Janeiro, RJ. 124 p. 